Jurnal The Messenger, Vol. 11, No. 1A, Special Issue on the School of Multimedia Technology and Communication Postgraduate Symposium, pp. 70-80

P-ISSN: 2086-1559, E-ISSN: 2527-2810

DOI: $10.26623 /$ themessenger.v11i1.817

\title{
Music and Its Familiarity Affection on Audience Decision Making
}

\section{Musik dan Familiaritasnya terkait Pengambilan Keputusan Audiens}

\author{
Syazwani Mahsal Khan', Norsiah Abdul Hamid', Sabrina Mohd Rashid ${ }^{1}$ \\ ${ }^{1}$ School of Multimedia Technology and Communication, Universiti Utara Malaysia, \\ Sintok, Kedah, Malaysia \\ *Corresponding author, e-mail: syazwani.mahsalkhan@gmail.com
}

\begin{abstract}
This article discuss a problem regarding the lack of using familiar music and its effect on audience decision making to buy advertised products or services. This study is to help the experts to maintain young audience focus while selling their products or services more effective using the familiar music in the advertisement content. The utilization method used for this study was in-depth interview, involved with ten informants which covered experts from academicians, advertising practitioners and musicians. It based on snowball sampling, because not all these experts have the knowledge on this issue. The Elaboration Likelihood Model was applied to show the process of decision making. Thematic analysis used to analyze two themes emerged from this study; Repetition of Musical Tone as Remembrance. This study may provide contribution in terms of ideas for music and advertising industry producing familiar catchy musical sound for their purpose.
\end{abstract}

Keywords: Music, Advertising, Familiar, Audience, Decision Making.

\begin{abstract}
Abstrak
Artikel ini membahas tentang kurangnya penggunaan musik yang familier dan pengaruhnya terhadap pengambilan keputusan audiens untuk membeli produk atau layanan yang diiklankan. Studi ini bertujuan membantu para ahli untuk mempertahankan fokus audiens muda, agar lebih efektif dalam menjual produk atau layanan mereka menggunakan musik yang familier dalam konten iklan. Metode yang digunakan untuk penelitian ini adalah wawancara mendalam, yang melibatkan sepuluh informan yang mencakup pakar dari akademisi, praktisi periklanan, dan musisi. Ini didasarkan pada model pengambilan sampel bola salju, karena tidak seтиa ahli tersebut memiliki pengetahuan tentang masalah ini. Elaboration Likelihood Model diterapkan untuk menunjukkan proses pengambilan keputusan. Analisis tematik yang digunakan untuk menganalisis dua tema yang muncul di penelitian; Pengulangan Nada Musik sebagai Pengingat. Studi ini dapat memberikan kontribusi dalam hal ide-ide untuk industri musik dan periklanan yang menghasilkan suara musik yang mudah diingat untuk mencapai
\end{abstract} tujuan mereka.

Kata Kunci: Musik, Periklanan, Familier, Audiens, Pengambilan Keputusan.

\section{Introduction}

Advertising can be associated with global entertainment industry that include the consumer magazines, newspapers, radio, television, music, filmed entertainment, video games, social media, mobile apps and many more (Hollebeek, Malthouse, \& Block, 2016). Music video inspires the viewer to associate the purchase of consumer products featured in the clips with desirable emotions and values in advertisement (Banks, 2018).

Advertising brings important means by the companies to communicates with their audience both current and potential in situation (Bendixen, 1993). The advertising function is to create awareness for a new or brand products, and to inform consumers of 
the features and benefits of products or brand (Bendixen, 1993). It is nowadays advance, fast and uptodate and it is global and practically cannot be escaped especially for the normal audience (Harker, 2000; Watie, 2012).

Furthermore, advertising cannot be escaped from using music because its role to persuade audience (Alpert, Alpert, \& Maltz, 2005; Oakes, 2007) to buy the advertised products or services. Advertising and music are inseparable as it can create awareness for the audience to watch the advertisement. This is because more than 90 percent music is incorporated in advertising as one of the creative elements in it (Kellaris, Cox, \& Cox, 1993). As stated by Alpert and Alpert (1990) music in advertising could affect the audience mood and persuade them to make decision to buy a particular product.

In fact, music in advertising has always been treated as one dimensional variable in research study. For instance, past research have investigated the advertising effects of music variables on consumer attitudes (Allan, 2007) music and attitude toward the advertisements (North, MacKenzie, Law, \& Hargreaves, 2004), music and attitude toward the brand (Brooker \& Wheatley, 1994), music and purchase intention (Alpert \& Alpert, 1990), pleasure and arousal, (Alpert \& Alpert, 1990) and personal significance (Allan, 2006).

However, the influence of music on cognitive and affective response to advertising has received less attention than it may deserve (Oakes, 2007). Teixeira (2014) explained that even companies are struggling for their advertisement, it is st1ll not strong enough at reaching the audience as they do not pay attention to it. Audience especially young target audience want something that can entertain them. One of the main reason of this is using the music that they familiar with. By using this, it could increase their feeling to feel entertaining. Music is used to attract attention, identification, association and remembrance (Jain \& Bagdare, 2011) in advertisement of products and services.

Thus, there is a lack of focusing on musical familiarity and its effect toward the young audience in making decision to buy a particular product and services. Hence, this research will open new ideas on how to engage young audience and persuade them to make decision to buy a particular products and services through musical familiarity in advertisements.

Familiarity is something that people already knew, something that can be predicted (Prior, 2016). It is more towards something that less challenge, more towards routine lifestyle or something that people always do such as housework, driving, shopping and many more. When it comes to musical familiarity, the repeated stimuli of music can generate positive affect (Garcia-Marques, Mackie, Claypool, \& GarciaMarques, 2004) which can support people engagement through melody. In fact, musical familiarity will have the highest level of hedonic value on an individual's emotion (Barrett, Ashley, Strait, \& Kraus, 2013).

Music and its familiarity is required for audience to produce it from memory (Roehm, 2001). Music that is in form of instrumental sound is more likely to be familiar to the audience in inducing advertising message recall while audience with unfamiliar with the song the vocal version of message was more effective (Roehm, 2001).Other than that, the familiarity of music will rise the likeness of audience toward the advertised product and service in advertisement. Familiar music may infiltrate the mind, repeat itself continuously and become extremely difficult to remove by the audience (Abolhasani, Oakes, \& Oakes, 2017).

Jurnal The Messenger, Vol. 11, No. 1A, Special Issue on the School of Multimedia Technology and Communication Postgraduate Symposium, pp. 70-80 
Advertisers want to induce positive emotions that the audience discover it as pleasant with music in order to associate those positive emotions with their own brand or product (Blecha, 2015). Familiarity is used in commercial advertisements, in which it enables the information of a product coded in memory (Heaton \& Paris, 2006). Factors that may interact with music comprise the audience characteristics for example, familiarity with the music, type of product, pictures, or other extra-musical meanings in the message of advertising (Shevy \& Hung, 2013). Hence, music and its familiarity in advertising of products and services is important in order to attracts its target audience. This is because increased familiarity believably leads to improved processing and less perceived complexity (Madison \& Schiölde, 2017).

Musical familiarity can leads to audience in decision making. Mood and arousal that evoked by music can give impact to audience who depend on their gut feelings to make a decision (Shevy \& Hung, 2013) to buy the advertised products or services. The engagement of consumers with music may arise motivational states which happen by the advantage of person's interactive experiences with specific object (Hollebeek et al., 2016) such as products, services, or artists in the television advertisement commercial.

In addition, audience who are familiar with certain music genre will makes them trust in terms of making decision to buy the advertised products and services. Litt, Reich, Maymin, and Shiv (2011) state that familiarity preference sometimes can be sensible or adaptive. In this case, a good music which is combined with message in the commercial advertisement may reduce cognitive load, create a favourable attitudes and assist the consistent meaning development (Shevy \& Hung, 2013).

Literature state that music can give strong impact on people emotionally (Leipold \& Loepthien, 2015; Miranda \& Claes, 2009) which means it is more on intrinsically driven towards human feeling. When it comes to advertising and marketing perspectives, consumers or audience always make a choice by their intrinsic feeling regarding product and service in advertisement or in the market. Bagga and Bhatt (2013) states that consumers who want to make decision to buy products or services are more towards internally driven while extrinsic factors have low impact as compared tointrinsic factors. Hence, the intrinsic are stronger which can influence the target audience to buy related products or services advertised in television, radio or social media. With regards to the issues mentioned earlier, the research question of this study is to what extent the music and its familiarity could affect the decision making of young audience to buy advertised products and services

Past researcher have used the Elaboration Likelihood Model theory in advertising and marketing perspective as this is the suitable theory for attitude and behaviour study of consumer. This theory has two routes of persuasion, which is central and peripheral (Petty, Cacioppo, \& Schumann, 1983; Petty, Kasmer, Haugtvedt, \& Cacioppo, 1987). The central route needs a deep concentration on explanation of the information and opinions gained. Meanwhile, peripheral route need a simple association, experiences, and interpretations to catalyse the attitude change (Petty et al., 1987).

This study applies the peripheral routes of persuasion as it is suitable with music and its familiarity to be engaged with the young audience towards the advertised products and services that related to them. Young audience normally engage with purchase decision that can be influenced by the available information (Nizam, Jaafar, \& Supaat, 2018) where it does not require deep elaboration (Petty et al., 1987) in which it is only based on the attitude of the consumer towards the product or services (Nizam et al., 2018). 
Besides, individuals can recall the brand or product when they get familiar with its music in the advertisement (Strähle \& Keibel, 2018). A study done by Ayada (2017) shows that the sentimental advertisements in terms of familiar music evoke a more positive attitude toward the advertisement and advertised brand. Music and advertisement message enhanced the elicitation of desired (positive) affective responses to the advertisement content recall (Oakes \& North, 2006). Hence, Peripheral routes use more on affective advertisement message that include the simple association that relates with the consumer experience.

\section{Methodology}

This research applies qualitative approach as it requires an in-depth interpretation. The research question relates to the Elaboration Likelihood Model because it is the persuasion theory (Cacioppo \& Petty, 1984; Petty \& Cacioppo, n.d.; Rollins \& Bhutada, 2014; Shevy \& Hung, 2013) in which the use of music for this study is suitable for exploring its effect on consumer through experience.

Furthermore, using the in-depth interview for this research is needed to have a clear understanding of a phenomenon (Tully, 2014). Qualitative approach is very suitable in order to figure meanings and experiences from the expert because it can fulfill the need of new knowledge.

There are three experts from advertisers, three experts from musicians and four experts from academicians. They are experts in Malaysia and the criteria of choosing them is based on their experience of working in the field (Libakova \& Sertakova, 2015) at least for ten years. The indepth interview was taken place at their companies and some at their universities. The interview was held on March 2017 till June 2017 including on the work of transcribing the data and producing initial code.

As said by O'Reilly and Parker, (2013); and Walker, (2012) that data saturation is reached when there is enough information to reproduce the study, and also when the ability to acquire additional new information has been achieved, (Guest, Bunce, \& Johnson, 2006) and when the added coding is no longer possible (Guest et al., 2006).

This study applies snow-ball sampling as it is widely employed method in qualitative research on hard-to-reach populations (Heckathorn, 2011). The characteristic of snowball sampling is that it is not used to evaluate the characteristics of the general population but to evaluate the characteristics of a network of 'hidden' populations such as rare cases and difficult to identify (Dragan \& Isaic-Maniu, 2013). The meaning of 'hidden' in other words, due to their rarity, this type of population is difficult to find, to study and to recruit for the compulsory investigation (Dragan \& Isaic-Maniu, 2013).

In this case of study, not all academicians, musicians and advertisers have the knowledge on this issue. This study uses snowball sampling in order to find the correct and suitable participant to obtain rich and detailed knowledge regarding the issue. As Atkinson and Flint (2001) stated that the tactics of using snowball sampling is that someone in the group would know others to whom a researcher could be directed to.

By using the snowball sampling, these three groups of experts are believed to have the richest data in understanding the music in television advertising and audience decision making perspectives. Findings from the interviews could bring the new knowledge in finding the effects of musical familiarity towards audience decision making.

The data of this study has analysed using thematic analysis and coded line by line on the findings using recoding units. Then it was sent for validity and reliability via

Jurnal The Messenger, Vol. 11, No. 1A, Special Issue on the School of Multimedia Technology and Communication Postgraduate Symposium, pp. 70-80 
member checking where the results and interpretations are taken back to the participants with the purpose of confirmation and validation on the data findings (Zohrabi, 2013). Thematic analysis is used to analyse classifications and present themes or patterns that has linkage to the data (Alhojailan, 2012). It is the most suitable for any study that find to discover using interpretations (Alhojailan, 2012). It offers a systematic component to data analysis as it allows the researcher to associate the frequency analysis of a theme with one of the whole content (Alhojailan, 2012) Hence, the researcher has to make sense of the data by discovering and interpret it (Burnard, Gill, Stewart, Treasure, \& Chadwick, 2008).

\section{Results and Discussion}

The ten experts have experiences in their own position of working. Three advertisers experiences are almost 10 years in producing and composing music for the advertisements content. Three musicians where each of them have experience in producing and composing music video or songs almost for 30 years, and the four of academicians have experience in music studies regarding music composition in many areas, such as music advertisement, music video, traditional and modern music composition research almost 10 years.

In findings there are two themes emerged from this study on how the music and its familiarity effects the decision making of young audience. The themes are (i) repetition of musical tone, and (ii) music as remembrance.

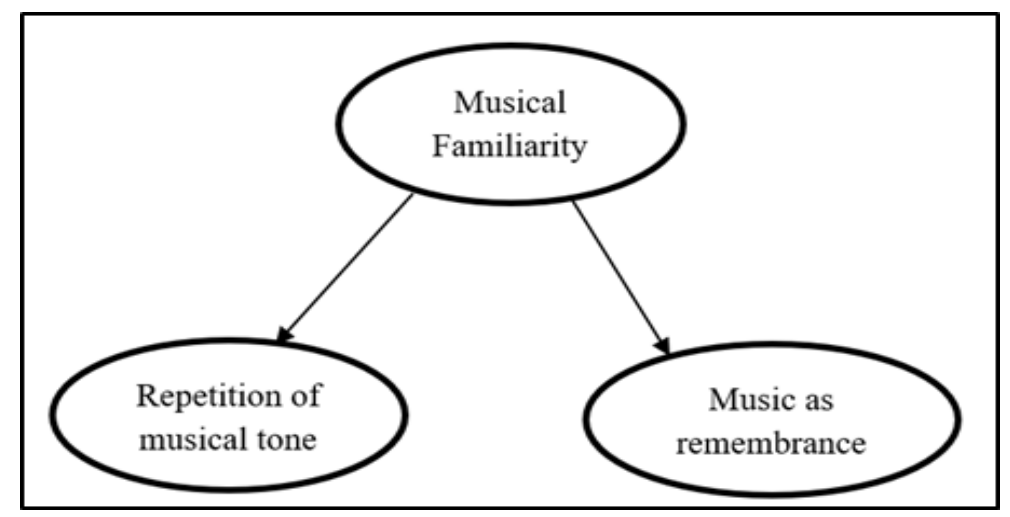

Figure 1. Musical and Its familarity Affects Audience Desicion Making

(Source: Author's analysis)

Based on data analysis, seven informants have emphasised that repitition of musical tone does effect the audience in decision making. As stated by Brader (2005) when audience exposed to the positive enthusiastic image with music show larger interest under the condition of consumer's feeling less risk (Lim, 2003) in making decision to buy the advertised products or services. For instance, (Informant 2) talks about the repetition of music in advertised product compared to the advertised service.

“... repeating ... (music) is usually (for advertised) product alright? Compare to service ad, usually when you listen to jingle always, if we listen so many times, we feel okay, I need to try this out. Because always have seen it on tv commercial." (Informant 2). Informant 4 and Informant 8 have similar argument as Informant 2 . They said: “... if you expose with the message daily and for a long period of time, it will makes you feel somehow you need to buy this or try this out." "When they (audience) watch advertisement with good music, they will watch again and again and then eventually they will buy things" (Informant 8). 
Furthermore, Informant 7 gives an example regarding the repetition of musical tones that indirectly could affect the visual advertisement as well as consumers mind. "Like Huawei, they are using the beats that I like ... the dancing beat then subconsciously I might like this product ... subconsciously. It is not first level of attack, its like second level or third level in mind" (Informant 7).

According to Abolhasani et al. (2017) the use of extremely addictive and repetitive types of music in advertisements may have positive effects on consumers' responses. Thus, the repetition of musical tone could affects audience in making decision as it evoke a positive attitude toward the advertisement and advertised brand (Ayada, 2017). This is in line with the peripheral route of the Elaboration Likelihood Model Theory where consumer will not require deep focus on the elaboration of advertisements (Petty et al., 1987) but it is more towards affective states of mind that persuades the audience to buy the advertised products and services.

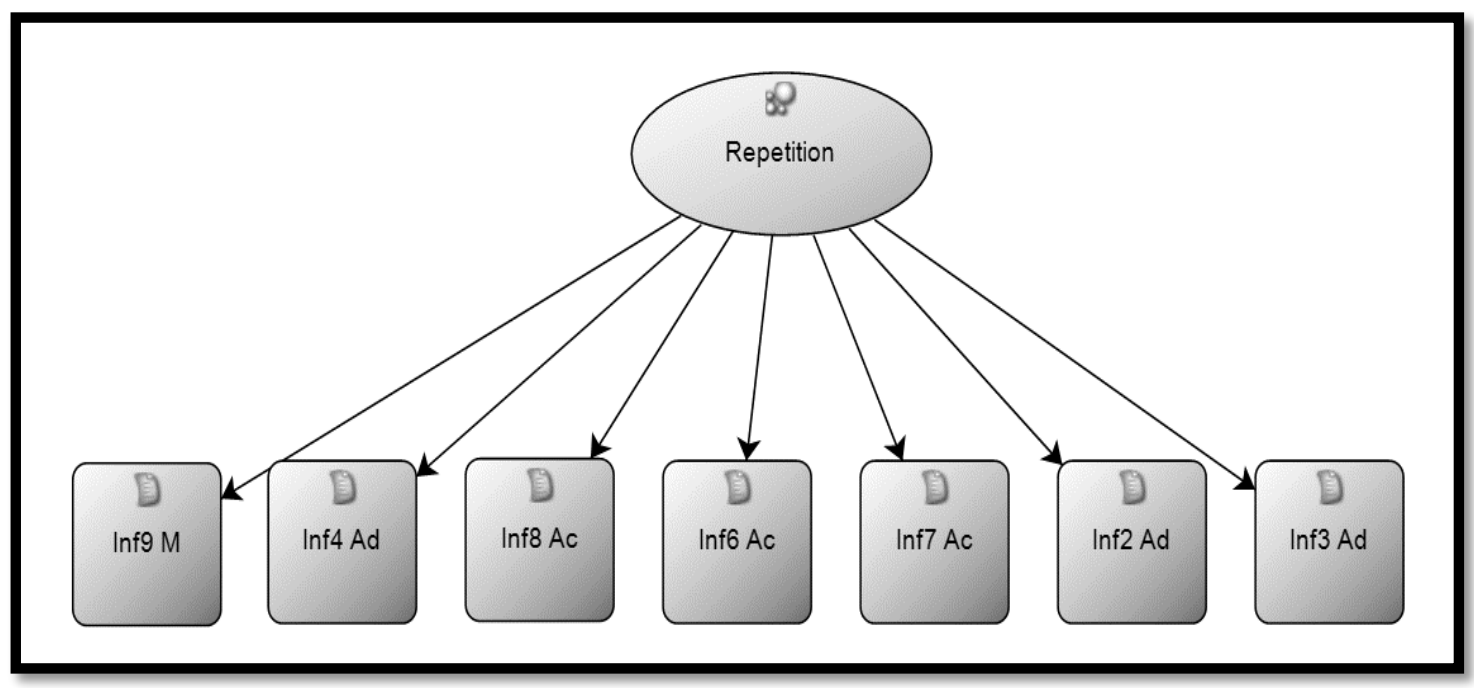

Figure 2. Repetition of Musical Tone Affects Audience Decision Making (Source: Author's analysis)

The second theme emerged from the analysis is music as remembrance. There are 9 Informants emphasised on music as remembrance. As stated by Heaton and Paris (2006) music can make the audience remember the advertisement and also strengthen the brand recall (Strähle \& Keibel, 2018). For instance, Informant 10 and Informant 3 talks about the 'musical hook' in which it can become memorable sounds in consumer's mind. They said:

"The 'hook' would play in the listener's mind and make him keep thinking of the product. When it's time for a purchase the hook will enhance top of the mind recall" (Informant 10). “... it's something catchy you have to do ... something memorable, so that's why it is called hook ... But normally, hook you use it normally as for the theme song of the brand for example, parappapaaa. that is the hook. And you have other tunes like Calpis voice, $p, p, p, p, p, p$ you know, that's is the hook. So that's all hook, something that catchy ... that simple, and people can remember ... it will remind you of the brand. Its more on remind you of the brand" (Informant 3 ).

Informant 2 talks about the remembrance of a piece of music could leads the consumer to buy the product. She says, "if a person going to anywhere and suddenly saw the product so they can ooo ... This product ... oo ... And it might give the client or end user interest so they can buy the product if they don't remember they won't buy it."

Jurnal The Messenger, Vol. 11, No. 1A, Special Issue on the School of Multimedia Technology and Communication Postgraduate Symposium, pp. 70-80 
According to Huron (1989), states that the important function of music is to increase the memorability of a product or the products name as it leads to purchase decision by the audience who watch the advertisement. When the audience recall the product, they will go for simple decision to buy the advertised product that they familiar with. Hence, the finding above regarding music as the hook in which it leads to remembrance is in line with (Huron, 1989) as he states that 'Jingle" is the most common musical technique for aiding memorability and product recall.

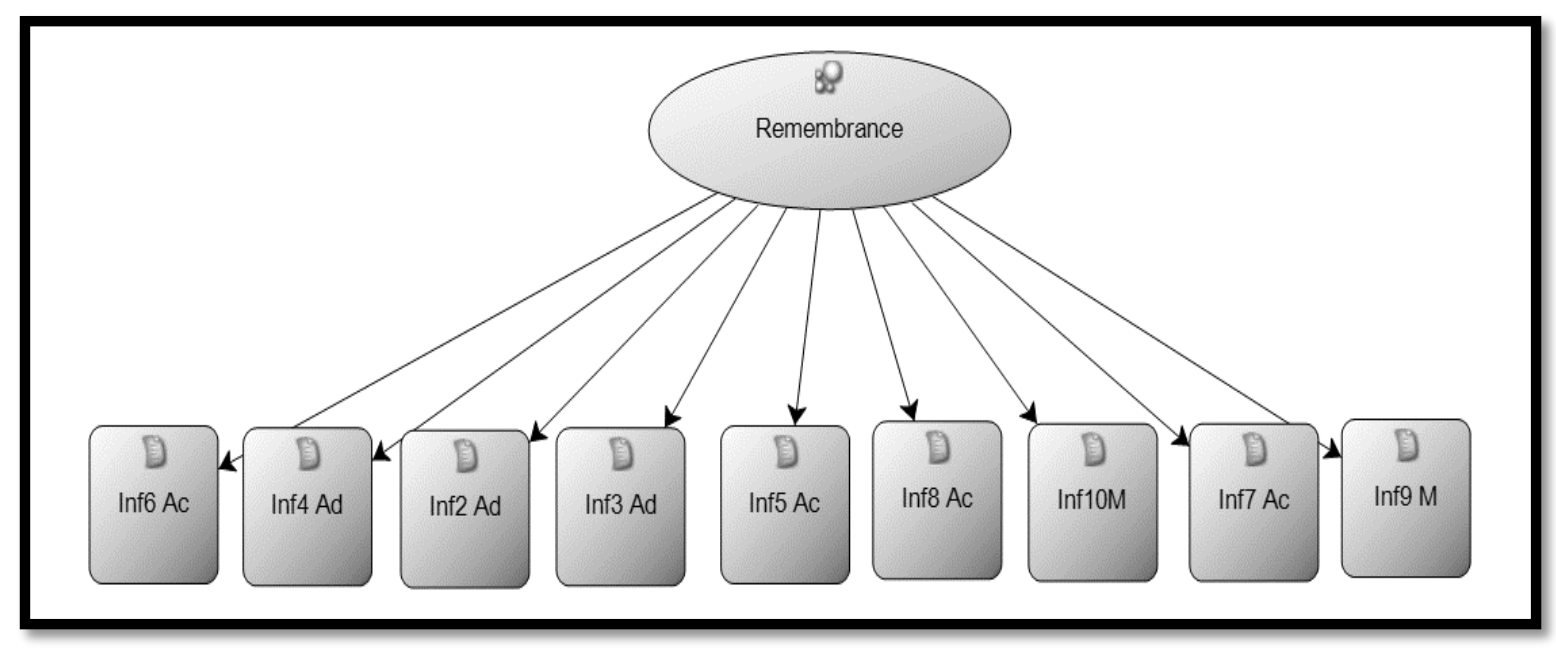

Figure 3. Music as Remembrance Affects Audience Decision Making (Source: Author's analysis)

\section{Conclusion}

This article has discussed mainly on the issue related to music in advertising. The result of this study is hoped to provide insight on the effects of musical familiarity towards the audience decision making. The finding from this research may provide contribution in two areas which is advertising industry and also music industry on producing familiar tone but catchy sounds for advertising perspectives. This result has showed that the familiarity of music in advertisement could give an effect to the young audience in making decision to buy the advertised products and services.

Young audience especially likes the product because of the music that they familiar with. Music can be entertaining for audience in advertising because it rules the commercial (Craton, Lantos, \& Geoffrey, 2011). Much of advertisement nowadays are more focus on young audience and kids (Hassan \& Daniyal, 2013). Hence, it is believed that advertising will affect the decision making on the purchase of advertised products and services (Putri, 2016).

The findings indicates that the use of music especially the familiar music for selling the product and services through advertisement is a vital element as it could help the seller to gain their profit effectively. Indirectly, through this tactics could expand the economic country to the world.

For the practical perspective, this study could bring an understanding or idea in using the music that becomes the familiar one to the audience in order to encourage and also to persuade them psychologically to buy the advertised product and service. Thus, this study would be fruitful for advertisers and musicians and indirectly it contribute some knowledge to academicians as well. 
The implication of this study is that the study is appropriate to the theory of Elaboration Likelihood Model. This shows that the music and its familiarity will use the peripheral routes as the stimuli for advertising in which it affects the audience decision making when watching the advertisement content. When audience exposes to the music and its familiarity, indirectly they use the peripheral routes where they will have a simple decision on buying the related product in the advertisement content.

The limitation in this research is the researcher could not know the advertisers routine to see the problem in their work place dealing with client or having technical problem. Other than that, there is more interesting issue that the researcher could explore in terms of music video in advertising with today's culture issue in terms of to see how culture could relates with the music in advertisement and how the video advertisement could depict those culture to audience. For future research it would be best to explore in this two issues.

\section{Acknowledgements}

We would like to thank all experts and informants, as well as other parties directly, and indirectly involved in this research.

\section{References}

Abolhasani, M., Oakes, S., \& Oakes, H. (2017). Music in advertising and consumer identity: The search for Heideggerian authenticity. Marketing Theory, 17(4), 473490.

Alhojailan, M. I. (2012). Thematic Analysis: A critical review of its process and evaluation. In WEI International European Academic Conference (pp. 8-21).

Allan, D. (2006). Effects of popular music in advertising on attention and memory. Journal of Advertising Research, 46(4), 434-444. https://doi.org/10.2501/S0021849906060491

Allan, D. (2007). Sound Advertising: A Review of the Experimental Evidence on the Effects of Music in Commercials on Attention, Memory, Attitudes, and Purchase Intention. Journal of Media Psychology, 12(3), 1-35.

Alpert, J. I., \& Alpert, M. I. (1990). Music influences on mood and purchase intentions. Psychology \& Marketing, 7, 109-133.

Alpert, M. I., Alpert, J. I., \& Maltz, E. N. (2005). Purchase occasion influence on the role of music in advertising. Journal of Business Research, 58, 369-376.

Atkinson, R., \& Flint, J. (2001). Accessing Hidden and Hard-to-Reach Populations: Snowball Research Strategies. Social Research Update, 1-4. Retrieved from internal-pdf://95.245.58.229/SRU33.pdf

Ayada, W. M. (2017). influence behaviour of brands consumers (An Analytical study on TV advertisement campaigns in Egypt), 327-343.

Bagga, T., \& Bhatt, M. (2013). A Study of Intrinsic and Extrinsic Factors Influencing Consumer Buying Behaviour Online. Asia-Pacific Journal of Management Research and Innovation, 9, 77-90.

Banks, J. (2018). Monopoly Television MTV's Quest to Control The Music. Routledge.

Barrett, K. C., Ashley, R., Strait, D. L., \& Kraus, N. (2013). Art and science: how musical training shapes the brain. Frontiers in Psychology, 4.

Bendixen, M. T. (1993). Advertising Effects and Effectiveness. European Journal of Marketing, 27(10), 19-32. https://doi.org/10.1108/09574090910954864

Blecha, M. (2015). The Impact and Interaction of Music Familiarity and Congruency on

Jurnal The Messenger, Vol. 11, No. 1A, Special Issue on the School of Multimedia Technology and Communication Postgraduate Symposium, pp. 70-80 
Responses to Advertisements. Retrieved from internal-pdf://79.117.116.60/Blecha Brader, T. (2005). Striking a responsive chord: How political ads motivate and persuade voters by appealing to emotions. American Journal of Political Science, 49, 388405.

Brooker, G., \& Wheatley, J. (1994). Music and radio advertising: effects of tempo and placement. Advances in Consumer Research, 21, 286-291. Retrieved from http://www.acrwebsite.org/volumes/display.asp?id=7606

Burnard, P., Gill, P., Stewart, K., Treasure, E., \& Chadwick, B. (2008). Analysing and presenting qualitative data. British Dental Journal, 204, 429-432.

Cacioppo, J. T., \& Petty, R. E. (1984). The elaboration likelihood model of persuasion. NA-Advances in Consumer Research Volume 11.

Craton, L. G., Lantos, G. P., \& Geoffrey, P. (2011). Attitude toward the advertising music: an overlooked potential pitfall in commercials. https://doi.org/10.1108/07363761111165912

Dragan, I.-M., \& Isaic-Maniu, A. (2013). Snowball sampling completion. Journal of Studies in Social Sciences, 5(2), 160-177.

Garcia-Marques, T., Mackie, D. M., Claypool, H. M., \& Garcia-Marques, L. (2004). Positivity Can Cue Familiarity. Personality and Social Psychology Bulletin, 30(5), 585-593. https://doi.org/10.1177/0146167203262856

Guest, G., Bunce, A., \& Johnson, L. (2006). How Many Interviews Are Enough ? An Experiment with Data Saturation and Variability. Family Health International, 18(1), 59-82. https://doi.org/10.1177/1525822X05279903

Harker, D. (2000). Complaints about advertising: what is really happening ?, 3(4), 198206.

Hassan, A., \& Daniyal, M. (2013). Impact of Television Programs and Advertisement on School Going Adolescents: A Case Study of Bahawalpur City, Pakistan. Bulgarian Journal of Science and Education Policy, 7, 26. Retrieved from internal-pdf://44.0.3.74/(Hassan \& Daniyal, 2013.pdf

Heaton, M., \& Paris, K. (2006). The Effects of Music Congruency and Lyrics on Advertisement Recall. Journal of Undergraduate Research IX.

Heckathorn, D. D. (2011). Comment: Snowball versus respondent-driven sampling. Sociological Methodology. https://doi.org/10.1111/j.1467-9531.2011.01244.x

Hollebeek, L. D., Malthouse, E. C., \& Block, M. P. (2016). Sounds of music: exploring consumers' musical engagement. Journal of Consumer Marketing, 33(6), 417427. https://doi.org/10.1108/JCM-02-2016-1730

Huron, D. (1989). Music in advertising: An analytic paradigm. Musical Quarterly, 557574.

Jain, R., \& Bagdare, S. (2011). Music and consumption experience: a review. International Journal of Retail \& Distribution Management, 39, 289-302.

Kellaris, J. J., Cox, A. D., \& Cox, D. (1993). The effect of background music on ad processing: A contingency explanation. The Journal of Marketing, 114-125.

Leipold, B., \& Loepthien, T. (2015). Music reception and emotional regulation in adolescence and adulthood. Musicae Scientiae, 1029864915570354.

Libakova, N. M., \& Sertakova, E. A. (2015). The Method of Expert Interview as an Effective Research Procedure of Studying the Indigenous Peoples of the North. Journal of Siberian Federal University. Humanities \& Social Sciences, 1(8), 114129.

Lim, N. (2003). Consumers' perceived risk: sources versus consequences. Electronic 
Commerce Research and Applications, 2(3), 216-228.

Litt, A., Reich, T., Maymin, S., \& Shiv, B. (2011). Pressure and Perverse Flights to Familiarity. Psychological Science, 22(4), 523-531. https://doi.org/10.1177/0956797611400095

Madison, G., \& Schiölde, G. (2017). Repeated listening increases the liking for music regardless of its complexity: Implications for the appreciation and aesthetics of music. Frontiers in Neuroscience, 11(MAR), 1-13. https://doi.org/10.3389/fnins.2017.00147

Miranda, D., \& Claes, M. (2009). Music listening, coping, peer affiliation and depression in adolescence. Psychology of Music, 37, 215-233.

Nizam, N. Z., Jaafar, J. A., \& Supaat, S. H. (2018). Interactive Online Advertising: The Effectiveness of Marketing Strategy towards Customers Purchase Decision, 5043, $1-6$.

North, A. C., \& Hargreaves, D. J. (1998). The effect of music on atmosphere and purchase intentions in a cafeteria1. Journal of Applied Social Psychology, 28, 2254-2273.

North, A. C., MacKenzie, L. C., Law, R. M., \& Hargreaves, D. J. (2004). The Effects of Musical and Voice "Fit" on Responses to Advertisements1. Journal of Applied, 34, 1675-1708. https://doi.org/10.1111/j.1559-1816.2004.tb02793.x

O’Reilly, M., \& Parker, N. (2013). "Unsatisfactory Saturation”: A critical exploration of the notion of saturated sample sizes in qualitative research. Qualitative Research, 13(2), 190-197. https://doi.org/10.1177/1468794112446106

Oakes, S. (2007). Evaluating empirical research into music in advertising: A congruity perspective. Journal of Advertising Research, 47, 38-50.

Oakes, S., \& North, A. C. (2006). The impact of background musical tempo and timbre congruity upon ad content recall and affective response. Applied Cognitive Psychology, 20(4), 505-520. https://doi.org/10.1002/acp.1199

Petty, R. E., \& Cacioppo, J. T. (n.d.). The Elaboration Likelihood Model of Persuasion (Vol. 19). Academic Press. Inc. Retrieved from internalpdf://203.208.183.103/1986 Petty Cacioppo- the ELM of persuasion.pdf

Petty, R. E., Cacioppo, J. T., \& Schumann, D. (1983). Central and peripheral routes to advertising effectiveness: The moderating role of involvement. Journal of Consumer Research, 135-146.

Petty, R. E., Kasmer, J. A., Haugtvedt, C. P., \& Cacioppo, J. T. (1987). Source and message factors in persuasion: A reply to Stiff's critique of the elaboration likelihood model.

Prior, H. M. (2016). Music and Familiarity: Listening, Musicology and Performance. Routledge.

Putri, P. K. (2016). Aplikasi Pendekatan-Pendekatan Persuasif Pada Riset Komunikasi Pemasaran: Iklan Melibatkan Penciptaan dan Penerimaan Pesan Komunikasi Persuasif Mengubah Perilaku Pembelian. Jurnal The Messenger, 8, 1-16.

Roehm, M. L. (2001). Instrumental versus vocal versions of popular music in advertising. Journal of Advertising Research, 41, 49-58.

Rollins, B., \& Bhutada, N. (2014). Impact of celebrity endorsements in disease-specific direct-to-consumer (DTC) advertisements: An elaboration likelihood model approach. International Journal of Pharmaceutical and Healthcare Marketing, 8, 164-177.

Shevy, M., \& Hung, K. (2013). Music in television advertising and other persuasive

Jurnal The Messenger, Vol. 11, No. 1A, Special Issue on the School of Multimedia Technology and Communication Postgraduate Symposium, pp. 70-80 
media. The Psychology of Music in Multimedia, 315-338.

Strähle, J., \& Keibel, M. (2018). Music in fashion communication. In Fashion \& Music (pp. 93-115). Springer.

Teixeira, T. S. (2014). The rising cost of consumer attention: Why you should care, and what you can do about it. Retrieved from internalpdf://183.114.164.138/Teixeira2014.pdf

Tully, M. P. (2014). Research: articulating questions, generating hypotheses, and choosing study designs. The Canadian Journal of Hospital Pharmacy, 67.

Walker, J. L. (2012). The use of saturation in qualitative research. Canadian Journal of Cardiovascular Nursing = Journal Canadien En Soins Infirmiers CardioVasculaires, 22, 37-46. https://doi.org/10.1007/s11747-007-0077-6

Watie, E. D. S. (2012). Periklanan Dalam Media Baru (Advertising in The New Media). Jurnal The Messenger, 4, 37-43.

Zohrabi, M. (2013). Mixed Method Research: Instruments, Validity, Reliability and Reporting Findings. Theory and Practice in Language Studies, 3(2), 254-262. https://doi.org/10.4304/tpls.3.2.254-262 